\title{
Partisipasi Tenaga Kerja Keluarga Usaha Ternak Sapi Potong Skala Kecil Studi Kasus di Kecamatan Tumpang, Kabupaten Malang Jawa Timur
}

\author{
U. Wisaptiningsih, B. Hartono, J.A. Putritamara* \\ Sosial Ekonomi Peternakan Fakultas Peternakan, Universitas Brawijaya, \\ J1. Veteran. Malang. Telp. 0341-553513 \\ *Email korespondensi: jaisyap@ub.ac.id
}

(Diterima: 26-06-2019; disetujui 10-08-2019)

\begin{abstract}
ABSTRAK
Tujuan penelitian adalah untuk menganalisis curahan tenaga kerja terhadap usaha sapi potong, analisis produktivitas teknik tenaga kerja dan faktor-faktor yang mempengaruhi produktivitas teknik tenaga kerja usaha peternakan skala kecil. Lokasi penelitian di kecamatan Tumpang, Kabupaten Malang, Jawa Timur. Jumlah responden 90 peternak. Analisis data menggunakan Structural Equation Model (SEM), software yang digunakan warpPLS 5.0. Hasil penelitian menunjukkan bahwa curahan kerja anggota keluarga (suami, istri dan anak) sebanyak 4 jam/hari. Curahan tenaga kerja non keluarga sebanyak $0,08 \mathrm{jam} / \mathrm{hari}$ yang digunakan untuk menncari hijauan. Produktivitas teknis usahaternak sapi potong tidak efisien dan Tingkat partisipasi anak terhadap usahaternak sapi potong $11 \%$. Model partisipasi tenaga kerja keluarga, jumlah kepemilikan ternak dan partisipasi anak terhadap usaha sapi potong memiliki pengaruh terhadap produktivitas teknis. Tingkat partisipasi anak dalan usahaternak sapi potong memiliki pengaruh positif terhadap produktivitas teknis tenaga kerja.
\end{abstract}

Kata Kunci: curahan tenaga kerja, partisipasi anak, produktivitas tenaga kerja, usaha sapi potong

\begin{abstract}
The research objective was to analyze the outpouring of labor for beef cattle business, the analysis of labor engineering productivity and the factors that influence the productivity of small-scale livestock business labor techniques. Research location in Tumpang sub-district, Malang Regency, East Java. The number of respondents 90 farmers. Data analysis using the Structural Equation Model (SEM), the software used warpPLS 5.0. The results showed that the workflow of family members (husband, wife and children) was 4 hours/day. Non-family labor was as much as 0.08 hours/day used to search forage. The technical productivity of beef cattle business was inefficient and the level of children's participation in the beef cattle business is $11 \%$. The model of family labor participation, the number of livestock ownership and child participation in the beef cattle business influence technical productivity. The level of participation of children in beef cattle business has a positive influence on the Technical Productivity of Labor.
\end{abstract}

Keywords: beef cattle business, child participation, labor productivity, the outpouring of labor

\section{PENDAHULUAN}

Usaha peternakan sapi potong di Indonesia mayoritas adalah peternak rakyat dengan kepemilikan kurang dari 3 ekor ternak karena terkendala modal. Sistem pemeliharaan hanya bersifat turun menurun (tradisional) dan ternak hanya sebagai tabungan yang sewaktuwaktu dibutuhkan dapat dijual karena beternak sapi potong bukan sebagai sumber utama pendapatan peternak. Padahal tujuan utama memelihara sapi potong adalah untuk meningkatkan perekonomian ekonomi rumahtangga peternak.

Beberapa masalah antara lain minimnya informasi terkait penyerapan tenaga kerja di sub sektor peternakan. Hal ini sesuai pendapat Fajri et al. (2016) bahwa skala usaha menentukan jumlah tenaga kerja yang digunakan, namun dengan curahan tenaga kerja dari keluarga masih belum dikatakan efektif untuk menangani 
usahaternak karena perhatian utama dipekerjaan lain yang sebagai sumber utama pendapatan peternak sehingga alokasi waktu yang digunakan untuk memelihara sapi potong lebih sedikit dibandingkan dengan curahan kerja sebagai pendapatan utama (Ratna, 2000). Produktivitas tenaga kerja di sektor pertanian dapat ditingkatkan dengan cara penge-lolaan yang lebih terencana dan ekonomis untuk mendapatkan hasil yang optimal dengan pemakaian tenaga kerja yang produktif dan efisien (Tatipikalawan, 2012)

Mayoritas peternak tradisional membagi pekerjaan dengan istri dan anaknya seperti mencari hijauan dan curahan kerja untuk memberi pakan ternak. Achmad et al. (2015) menjelaskan bahwa penggunaan dan ketersediaan tenaga kerja dihitung berdasarkan pengkonversian bentuk penyetaraan ke dalam tenaga kerja pria. Tenaga kerja pria dewasa memiliki nilai 1 HKSP (Harian Kerja Setara Pria) setara 8 jam/hari, wanita dewasa 0,8 HKSP dan anak-anak 0,5 HKSP.

Permasalahan muncul dengan adanya kemajuan teknologi sehingga anak peternak tidak memiliki minat untuk memberikan curahan tenaga kerjanya pada usahaternak. Semakin menurunnya minat anak maka usaha peternakan tidak akan berlanjut karena minat anak menentukan keberlanjutan usaha ternak. Akibatnya tidak ada generasi penerus yang dapat melanjutkan usaha ternak sapi potong dengan berkembangnya pengetahuan dapat dimungkinkan usaha peternakan sapi potong tidak berkelanjutan. Faktor tersebut yang menjadikan peluang daging impor masuk ke Indonesia akan semakin banyak karena peternakan rakyat sudah tidak lagi dapat memasok permintaan daging sapi dalam negeri sehingga upaya pengembangan budidaya sapi potong dihadapkan dalam masalah yang kompleks. Partisipasi anak dalam budidaya sapi potong benar-benar diharapkan sebagai produktiftas utama tenaga kerja dalam keluarga dan sebagai generasi penerus untuk melanjutkan usaha budidaya sapi potong sebagai sumbangsih daging sapi dalam negeri.Berdasarkan permasalahan diatas maka perlu dianalisis model pengembangan usaha ternak sapi potong skala kecil yang melibatkan tenaga kerja keluarga terutama anak.

\section{MATERI DAN METODE}

Penelitian dilaksanakan di kecamatan Tumpang Kabupaten Malang selama 6 bulan yaitu Maret-September 2018. Pemilihan lokasi penelitian yaitu kecamatan Tumpang, Kabupaten Malang dengan pertimbangan bahwa kecamatan Tumpang merupakan pinggiran kota malang dengan populasi ternak sapi potong skala kecil terbanyak, sebagai pionir penggalakan IB Propinsi Jawa Timur. Desain penelitian yang digunakan adalah survei dengan melakukan wawanacara kepada peternak sapi potong. Jumlah responden sebanyak 90 responden peternak sapi potong jenis lokal sebanyak 30 responden sedangkan persilangan seperti limousin-PO, simental-PO, brahman-abeeden angus sebanyak 60 responden. Analisis data menggunakan structural equation model (SEM) dengan software warPLS 5.0 untuk mendapatkan bentuk model dari produktivitas teknis tenaga kerja, sedangkan untuk melihat tingkat partisipasi anak dalam anggota keluarga terhadap usahaternak sapi potong dengan rumus SEM (Ghozali \& Latan, 2012):

$$
\begin{aligned}
\mathrm{Y}= & \mathrm{a}+\beta 1 \mathrm{X} 1+\beta 2 \mathrm{X} 2+\beta 3 \mathrm{X} 3+\beta 4 \mathrm{X} 4+\beta 5 \mathrm{X} 5 \\
& +\beta 6 \mathrm{X} 6
\end{aligned}
$$

Keterangan :

$$
\begin{aligned}
& \mathrm{Y}=\text { produktivitas teknik tenaga kerja } \\
& \mathrm{a}=\text { konstanta } \\
& \beta=\text { beta koefisien } \\
& \mathrm{X} 1=\text { pengalaman (tahun) } \\
& \mathrm{X} 2=\text { curahan tenaga kerja (jam/hari) } \\
& \mathrm{X} 3= \text { Pendapatan (Rp/bulan) } \\
& \mathrm{X} 4=\text { pendidikan } \\
& \mathrm{X} 5=\text { jumlah ternak (ST) } \\
& \mathrm{X} 6=\text { partisipasi anak dalam kegiatan usaha } \\
& \quad \text { ternak sapi potong }(\%)
\end{aligned}
$$

Varibel bebas meliputi pengalaman (x1), curahan tenaga kerja (x2), pendapatan (x3), pendidikan (x4), jumlah ternak (x5), Jumlah partisipasi anak (x6), sedangkan variabel terikat adalah produktivitas teknis tenaga kerja (Y). Partisipasi dan produktivitas teknis responden didapatkan rumus sebagai berikut.

$$
\begin{gathered}
\operatorname{partisipasi}(\%)=\frac{\sum \text { waktu anak yang berpartisipasi }}{\sum \text { waktu keluarga yang terlibat sebagai TK Sapi potong }} \times 100 \% \\
\text { Produktivitas Teknis }=\frac{\sum \text { ternak (ST) }}{\sum \text { Tenaga kerja (HKP) }}
\end{gathered}
$$




\section{HASIL DAN PEMBAHASAN}

Karakteristik peternak yang diamati meliputi pengalaman, pendidikan dan jumlah ternak yang dipelihara. Karakteristik responden merupakan faktor yang perlu dilakukan penelitian karena karakteristik merupakan faktor penting yang memiliki kontribusi terhadap peningkatan perekonomian peternak melalui pendapatan.

Tabel 1. Karakteristik Peternak

\begin{tabular}{lll}
\hline No & Variabel Pengamatan & Prosentase \\
\hline 1 & Pengalaman & \\
& $>10$ tahun & 47 \\
& $<10$ tahun & 53 \\
2 & Pendidikan & \\
& Tidak tamat Sekolah Dasar & 20 \\
& Sekolah Dasar & 45 \\
& SMP & 12 \\
& SMA & 23 \\
3 & Jumlah ternak & \\
& <3 ST & 86 \\
& Z3 ST & 14 \\
4 & Curahan Tenaga Kerja & \\
& Tenaga Kerja Keluarga & 94 \\
& Tenaga Kerja Non-keluarga & 6 \\
\hline
\end{tabular}

\section{Pengalaman Beternak}

Pengalaman beternak menentukan peternak dalam pengambilan keputusan terkait usahaternak bahkan mampu memperkuat posisi tawar akan penjualan sapi potong. Responden yang memiliki pengalaman usaha kurang dari 10 tahun dengan jumlah sebesar 47\%, sedangkan 53\% memiliki pengalaman diatas 10 tahun, rata-rata lama usaha responden menjalankan usahaternak sapi potong adalah 17 tahun. Pengalaman yang cukup karena umur peternak saat ini pada usia 36-50 dan 51-65 tahun, sehingga pada saat melaksanakan usaha pertama kali para peternak memiliki kisaran umurnya yang masih produktif. Semakin lama peternak menjalankan usaha, maka pengalaman dalam manajemen usahaternak semakin tinggi, sehingga apabila ada kendala, peternak lebih cepat mengambil tindakan. Prosentase pengalaman beternak di atas 10 tahun lebih tinggi karena usaha yang dijalankan bersifat turun temurun dan sebagai tabungan keluarga

\section{Pendidikan}

Pendidikan formal responden adalah pendidikan yang ditempuh, diukur dalam tahun yang diselesaikan. Responden yang tidak tamat SD dan tidak pernah menempuh pendidikan sekolah masih sekitar $20 \%$.
Peternak tidak tamat SD karena (1) Faktor ekonomi, banyak responden yang memiliki pekerjaan sebagai buruh tani dengan penghasilan yang kurang mencukupi untuk kehidupan sehari-hari; (2) Letak desa yang jauh dari kota kecamatan dan apabila akan melanjutkan sekolah yang lebih tinggi harus keluar desa dengan angkutan pedesaan yang saat ini hanya terdapat 1 angkutan setiap hari; (3) Motivasi lingkungan yang kurang, letaknya terpencil, banyak anak-anak kecil yang sudah membantu orang tuanya untuk bekerja di ladang, sehingga orientasinya adalah untuk mencari uang membantu orang tua dalam menghidupi keluarga.

Peternak dengan pendidikan terakhir SD sebanyak $45 \%$, untuk SMP $12 \%$ dan SMA 23\%. Hal tersebut mengindikasikan bahwa bekal pendidikan peternak di kecamatan Tumpang masih minim, sehingga sumberdaya manusia rendah. Harapannya semakin tinggi pendidikan peternak maka akan dengan mudah peternak mengadopsi ilmu yang ada terutama apabila memperoleh penyuluhan-penyuluhan yang berkaitan dengan usaha ternak bahkan semakin tinggi peternak di kecamatan Tumpang tergolong dalam fase peternak early adopters dan early majority.

Pendidikan tinggi merupakan bekal pengetahuan peternak untuk mengembangkan budidaya sapi potong, karena semakin tinggi pendidikan peternak maka semakin luas wawasan yang dimiliki oleh peternak. Seseorang yang berpendidikan tinggi cenderung lebih kritis dalam mengambil keputusan, artinya keputusan manajemen peternakan diambil tidak secepat peternak dengan pendidikan Sekolah Dasar. Tingkat pendidikan yang rendah menyebabkan seseorang kurang mempunyai keterampilan tertentu yang diperlukan dalam kehidupannya. Keterbatasan keterampilan/pendidikan yang dimiliki peternak menyebabkan keterbatasan kemampuan memanage usahasapi potong (Ahmadi, 2003).

\section{Jumlah Ternak}

Kepemilikan kurang dari 3 ST sebanyak $86 \%$ dan untuk kepemilikan lebih dari 3 ST sebanyak $14 \%$. Hal tersebut mengindikasikan bahwa tujuan masyarakat beternak bukan berorientasi untuk mendapatkan sumber penghasilan utama, karena beternak hanya bersifat turun menurun dari keluarga, beternak hanya bersifat sebagai tabungan yang sewaktu-waktu ternaknya dapat dijual ketika keluarga sedang 
membutuhkan uang. Komposisi ternak terdiri dari sapi dara sebanyak 0,11 ST, sapi muda jantan dengan jumlah $0,08 \mathrm{ST}$. Pedet jantan dengan rata-rata kepemilikan 0,14 . Pedet betina sebanyak 0,34 ST. Rendahnya kepemilikan ternak juga dikarenakan keterbatasan ekonomi sehingga belum bisa untuk menambah jumlah ternak.

Jumlah ternak merupakan faktor yang dianggap mampu memberikan kontribusi terhadap pendapatan peternak, dimana dengan kepemilikan ternak dalam jumlah banyak akan menutupi biaya yang dikeluarkan atau input produksi sehingga dapat meminimalisir terjadinya kerugian, hal tersebut sesuai dengan pendapat Siregar (2013) bahwa dengan skala kepemilikan ternak sapi potong yang banyak akan mempengaruhi pendapatan yang diperoleh peternak dimana semakin banyak kepemilikan ternak akan menambah jumlah penjualan serta dapat menekan biaya-biaya yang dikeluarkan dalam pemeliharaan ternak sapi potong.

\section{Curahan Tenaga Kerja Keluarga}

Curahan Tenaga kerja keluarga dalam usaha ternak sapo potong yang dipelihara tidak terlalu banyak sehingga guna mengefisiensikan pengalokasian biaya produksi maka peternak tidak menggunakan tenaga kerja luar keluarga. Penggunaan curahan kerja keluarga harapannya ketika ternak dijual akan mendapatkan keuntungan yang lebih tinggi dibandingkan dengan curahan tenaga kerja non keluarga. Pada curahan tenaga kerja keluarga peternak tidak memerlukan untuk mengeluarkan biaya variabel untuk memberikan upah tenaga kerja. Tenaga kerja dalam keluarga terdiri dari suami, istri dan anak. Perhitungan pengkonversian curahan tenaga kerja keluarga disetarakan dalam pria atau yang disebut dengan Hari Kerja Setara Pria (HKSP), sedangkan 1 HKSP setara dengan 8 jam kerja. Untuk suami bernilai 1 HKSP, istri bernilai 0,8 HKSP dan anak bernilai 0,5 HKSP.

Hasil konversi curahan tenaga kerja keluarga bahwa kegiatan usahaternak sapi potong diklasifikasikan menjadi tiga tugas yaitu mencari hijauan, membersihkan kandang dan pemberian pakan. Kegiatan tersebut dilaksanakan oleh anggota keluarga yang terdiri dari suami, istri dan anak. Kegiatan mencari rumput merupakan kegiatan yang dominan dilakukan oleh suami dengan nilai 2,29 jam/hari. Kegiatan mencari rumput diperlukan tenaga kerja laki-laki karena sistem pengambilan hijauan cut and carry sehingga membutuhkan tenaga lebih besar. Istri lebih banyak melakukan kegiatan membersihkan kandang karena asumsinya bahwa untuk kegiatan pembersihan perempuan lebih terampil dibanding-kan laki-laki. Kegiatan membersihkan kandang yaitu membersihkan lantai, membuang feses dan memandikan ternak. Kegiatan tersebut sesuai jika dilakukan oleh peempuan seperti ibu rumah tangga dalam membersihkan rumah. Waktu yang digunakan untuk membersihkan kandang adalah 0,35 jam/hari. Kegiatan dalam bentuk memberikan pakan pada ternak dilakukan oleh suami. Istri dan anak hanya berkontribusi dalam waktu yang kecil, bahkan istri hanya memberikan kontribusi sebanyak 0,09 jam/hari karena istri harus melakukan kegiatan lain seperti berumah tangga dan beberapa bekerja di sektor lain. Beberapa anak menempuh pendidikan dan bekerja di sektor lain. Suami berkontribusi dalam melakukan kegiatan pemberian pakan dengan waktu 0,31 jam/hari Seluruh kegiatan usahaternak sapi potong yang paling banyak berkontribusi adalah suami sebagai kepala rumah tangga yaitu sebanyak 2,92 jam/hari dari mencari rumput, membersihkan kandang dan pemberian pakan, sedangkan istri sebanyak $0,63 \mathrm{jam} / \mathrm{hari}$ dan yang paling sedikit berkontribusi adalah anak yaitu $0,44 \mathrm{jam} / \mathrm{hari}$. Hasil tersebut menunjukkan bahwa kurangnya kontribusi anak terhadap kegiatan usahaternak sapi potong.

\section{Curahan Tenaga Kerja Non Keluarga}

Tenaga kerja non keluarga merupakan sumberdaya manusia diluar keluarga yang memberikan kontribusi pada usaha ternak sapi potong. Banyaknya jumlah tenaga kerja yang dibutuhkan tergantung dari jumlah ternak yang dipelihara. Semakin banyak jumlah ternak maka semakin banyak pula jumlah tenaga kerja yang dibutuhkan. Adanya tenaga kerja non keluarga maka peternak memiliki konsekuensi untuk melakukan korbanan dalam bentuk pemberian upah tenaga kerja. Jumlah upah yang diberikan sesuai dengan kesepakatan antara tenaga kerja non keluarga dengan peternak. Hasil penelitian menunjukkan bahwa peternak lebih banyak menggunakan tenaga kerja non keluarga ketika melakukan kegiatan mencari rumput. Hasil perhitungan tenaga kerja dalam penyetaraan tenaga pria disajikan pada Tabel 2 .

Hasil penelitian menunjukkan bahwa tenaga kerja non-keluarga sebanyak $0,08 \mathrm{jam} /$ hari kegiatan mencari rumput, membersihkan 
Tabel 2 Curahan tenaga kerja usaha sapi potong

\begin{tabular}{llccccc}
\hline & \multicolumn{3}{c}{ Curahan Tenaga Kerja Keluarga } & & $\begin{array}{c}\text { Curahan Tenaga } \\
\text { Kerja Non Keluarga } \\
\text { (Jam /hari) }\end{array}$ \\
\cline { 2 - 5 } & Jenis Kegiatan & $\begin{array}{c}\text { Suami } \\
\text { (jam/hari) }\end{array}$ & $\begin{array}{c}\text { Istri } \\
\text { (jam/hari) }\end{array}$ & $\begin{array}{c}\text { Anak } \\
\text { (jam/hari) }\end{array}$ & $\begin{array}{c}\text { Total } \\
\text { (jam/hari) }\end{array}$ & \\
\hline 1 & Mencari rumput & 2,29 & 0,19 & 0,36 & 2,84 & 0,05 \\
2 & $\begin{array}{l}\text { Membersihkan } \\
\text { kandang }\end{array}$ & 0,32 & 0,35 & 0,04 & 0,71 & 0,01 \\
& Memberikan pakan & 0,31 & 0,09 & 0,04 & 0,44 & 0,02 \\
\hline
\end{tabular}

kandang dan pemberian pakan. Kegiatan yang paling banyak menggunakan tenaga kerja non keluarga adalah mencari rumput untuk menghemat waktu dan tenaga. Peternak yang memiliki jumlah ternak kurang dari 3 ST lebih memilih untuk menggunakan tenaga kerja keluarga dengan tujuan efisiensi biaya produksi.

\section{Faktor Produktivitas Teknis Tenaga Kerja}

Pengukuran model produktivitas teknis tenaga kerja adalah dengan analisis SEM dengan software warpPLS 5.0 sehingga diketahui faktor yang mempengaruhi produktivitas teknis tenaga kerja melalui bentuk model. Faktor yang menjadi pengukuran produktivitas teknis tenaga kerja (Y) dalam penelitian ini adalah pengalaman (x1), curahan tenaga kerja (x2), pendapatan (x3), pendidikan (x4), jumlah ternak (x5) dan partisipasi anak dalam anggota keluarga untuk berkontribusi dalam kegiatan usahaternak sapi potong (x6). Berikut merupakan hasil analisis dengan metode Structural Equation Model.

Tabel 3. Faktor produktivitas teknik tenaga kerja usahaternak sapi potong

\begin{tabular}{ll}
\hline Pengamatan & $\beta$ koefisien \\
\hline Konstanta & 0,206 \\
Pengalaman (X1) & 0,00 \\
Curahan tenaga kerja (X2) & $-0,53 * * *$ \\
Pendapatan (X3) & 0,09 \\
Pendidikan (X4) & $-0,03$ \\
Jumlah ternak (X5) & $0,39 * * *$ \\
Partisipasi anak terhadap kegiatan & \\
usaha ternak sapi potong (X6) & $0,20 * *$ \\
\hline
\end{tabular}

Berdasarkan hasil statistik, diketahui bahwa faktor-faktor yang berpengaruh terhadap produk-tivitas teknik tenaga kerja sapi potong di kecamatan Tumpang adalah curahan tenaga kerja, jumlah ternak yang dimiliki dan partisipasi anak terhadap kegiatan budidaya sapi potong. Faktor tersebut berpengaruh terhadap produktivitas teknik tenaga kerja sebesar 54\% dan sisanya sebesar $46 \%$ dipengaruhi oleh variabel lain di luar penelitian. Persamaan model struktural diperoleh sebagai berikut.

$$
\mathrm{Y}=0,206-0,53 \mathrm{X} 2+0,39 \mathrm{X} 5+0,20 \mathrm{X} 6
$$

Makna dari persamaan struktural tersebut bahwa walaupun tidak dilakukan pengamatan, maka produktivitas teknik sudah memiliki pengaruh sebesar $0,206 \%$. Menurunnya jumlah kontribusi tenaga kerja non keluarga yang dicurhakan untuk menjalankan usahaternak sapi potong 1 jam/hari maka akan meningkatkan Produktivitas Teknis Tenaga Kerja sebanyak 0,53 ST/Hari. Hasil tersebut mengindikasikan bahwa kontribusi tenaga kerja non keluarga menjadi faktor penyebab meningkatnya biaya produksi, karena jumlah ternak yang sedikit maka harus diimbangi dengan biaya produksi untuk mengeluarkan upah tenaga kerja. Pada kasus di desa Jeru kontribusi tenaga kerja dari keluarga menjadi satu-satunya opsi untuk mengurangi input produksi dalam meningkatkan laba. Hasil penelitian yang telah dilakukan dapat ditarik benang merah antara transparasi tenaga kerja di sektor peternakan, maka tidak salah jika pondasi perekonomian dari hasil PDRB bahwa sektor pertanian merupakan sumbangsih perekonomian terbesar setelah sektor industri.

Meningkatnya jumlah sapi potong yang dipelihara sebanyak 1 ST maka mampu menambah produktivitas Teknis Tenaga Kerja sebanyak 0,39 ST/Hari. Terdapat pengaruh antara curahan tenaga kerja dengan jumlah sapi potong. Hubungan keduanya positif dimana jumlah curahan kerja harus disesuaikan dengan jumlah ternak untuk menghindari inefisiensi input produksi. Jumlah tenaga kerja yang banyak namun jumlah ternak sedikit maka tidak akan terjadi efisiensi produksi teknis dan sebaliknya apabila jumlah ternak banyak namun tidak ada curahan tenaga kerja yang 
berkontribusi dalam menjalankan usahaternak, sehingga dpaat diindikasikan bahwa kurangya minat masyarakat terhadap pengembangan budidaya sapi potong karena banyak asumsi dari peternak di Jeru dan Benjor bahwa budidaya sapi potong hanya sebagai investasi dan bukan sebagai pekerjaan dengan sumber penghasilan utama.

Bertambahnya tingkat partisipasi anak dalam anggota keluarga untuk berkontribusi terhadap usahaternak sapi potong sebanyak 1 jam/hari maka mampu meningkatkan produktivitas teknis tenaga kerja sebanyak 0,20 ST/hari. Anak merupakan generasi penerus dimana kreativitas dan keterampilan anak dikembangkan sebagai bekal untuk meneruskan usahaternak sapi potong milik orang tua. Melalui kegiatan beternak harapannya dapat berkelanjutan dan meluas sehingga Indonesia tidak perlu memasok daging impor yang harganya membuat harga daging lokal tidak mampu bersaing, bahkan untuk memasok daging dalam negeri masih jauh dari nilai cukup.

\section{Produktivitas Teknik Tenaga Kerja}

Peningkatan produktivitas usaha meningkat apabila perbandingan antara input dengan output memiliki rasio yang seimbang. Beberapa kemungkinan yang terjadi ketika input produksi berkurang sedangkan output dalam jumlah tetap bahkan meningkat sesuai dengan prinsip dasar ekonomi maka kegiatan usahaternak sapi potong megalami peningkatan produktivitas.

Tabel 4. Perhitungan produktivitas teknis tenaga kerja

\begin{tabular}{ll}
\hline \multicolumn{1}{c}{ Pengamatan } & Nilai \\
\hline Rata-rata jumlah ternak & 1,58 \\
Jumlah tehaga kerja (HKSP) & 0,51 \\
Produktivitas teknik tenaga kerja (ST/hari) & 3,1 \\
\hline
\end{tabular}

Hasil penelitian menunjukkan bahwa produktivitas teknis usahaternak sapi potong di kecamatan Tumpang masih tidak efisien dengan nilai 3,1 ST/Hari, hasil tersebut diperoleh dari perbandingan antara rata-rata jumlah ternak dengan jumlah tenaga kerja yang dihitung dengan konversi hari kerja setara pria, maka nilai 4,11 jam/hari setara dengan 0,51 HKSP. Artinya setiap 1 hari kerja setara pria maka tenaga kerja mampu menangani 3 ekor sapi dewasa. Nilai inefisien disebabkan oleh jumlah ternak yang sedikit. Hasil wawancara dengan responden bahwa mayoritas peternak sapi potong tidak berorientasi pada sumber pendapatan keluarga akan tetapi hanya sebagai tabungan dan investasi sehingga sistem pemeliharaan yang seadanya. Menurut pendapat Sudono (2003), efisiensi penggunaan tenaga kerja di Indonesia sebaiknya enam sampai tujuh ekor sapi dewasa per orang tenaga kerja. Jika dibandingkan dengan pendapat Sudono (2003) tersebut, penggunaan tanaga kerja dalam usaha petemakan tersebut tidak efisien.

\section{Tingkat Partisipasi Anak dalam Anggota Keluarga terhadap Usahaternak}

Tingkat partisipasi merupakan perbandingan antara jumlah tenaga anak yang berpartisipasi dalam mencurahkan tenaganya untuk bekerja pada usahaternak sapi potong dengan jumlah tenaga kerja keseluruhan anggota keluarga yang memberikan kontribusi terhadap usahaternak sapi potong di desa Jeru dan Benjor. Masalah utama yang muncul adalah kurangnya minat seorang anak untuk bekerja pada sektor peternakan. Hal tersebut dikarenakan banyaknya pemuda yang memiliki asumsi bahwa bekerja di sektor peternakan membutuhkan banyak tenaga dan kurang bergengsi dibandingkan bekerja pada sektor lainnya. Apabila kasus tersebut tidak segera dibenahi maka seiring dengan bertambahnya tahun maka dunia peternakan akan semakin tenggelam dengan sektor lainnya, sedangkan kebutuhan protein hewani terus meningkat seiring dengan kemajuan teknologi karena kesadaran masyarakat untuk mengkonsumsi makanan mengandung gizi dari protein hewani. Berikut merupakan rata-rata hasil perhitungan tingkat partisipasi anak dari 90 responden dalam usahaternak di kecmatan Tumpang.

Tabel 5. Kontribusi curahan tenaga kerja anak terhadap budidaya sapi potong

\begin{tabular}{ll}
\hline \multicolumn{1}{c}{ Pengamatan } & Nilai \\
\hline $\begin{array}{l}\text { Rata-rata curahan tenaga kerja anak } \\
\text { (jam/hari) }\end{array}$ & 0,44 \\
$\begin{array}{l}\text { Rata-rata curahan tenaga kerja seluruh } \\
\text { anggota keluarga (jam/hari) }\end{array}$ & 4,11 \\
\hline
\end{tabular}

Berdasarkan perhitungan tingkat partisipasi anak terhadap usahaternak sapi potong diperoleh $11 \%$. Nilai tersebut diperoleh dari perbandingan antara rata-rata curahan tenaga kerja anak dengan rata-rata curahan tenaga kerja seluruh anggota keluarga. Hal tersebut menunjukkan minat anak yang kurang 
terhadap sektor peternakan, selain itu jumlah ternak yang dipelihara tidak terlalu banyak sehingga hanya suami dan istri yang terlibat langsung menangani ternak. Faktor pendapatan yang membuat anak lebih tergiur untuk bekerja pada sektor lain, membuat anak sedikit untuk tertarik bekerja di sektor pertanian. Selain masalah tersebut, banyak orang tua lebih memilih anaknya untuk bekerja di sektor lain karena beternak hanya sebagai pekerjaan sampingan atau sebagai ivestasi tabungan jangka panjang apabila sewaktu-waktu peternak membutuhkan dana tinggi untuk memenuhi kebutuhan. Asumsi lain bahwa anak tidak terlalu dilibatkan dalam menjalankan usaha budidaya sapi potong karena alasan orang tua agar anaknya lebih baik mendapatkan pekerjaan lain yang lebih bergengsi dibandingkan harus menjadi peternak.

\section{KESIMPULAN}

Curahan tenaga kerja keluarga terhadap usahaternak sapi potong adalah melalui kegiatan dari mencari hijauan, membersihkan kandang dan memberi pakan kepada ternak berturut-turut adalah 2,84 jam/hari; 0,71 jam/hari; dan 0,44 jam/hari sehingga dapat disimpulkan bahwa curahan kerja anggota keluarga dalam sehari rata-rata menghabiskan waktu 4 jam/hari. Curahan tenaga kerja non keluarga terhadap usahaternak sapi adalah 0,08 $\mathrm{jam} / \mathrm{hari}$ yaitu sekitar $62,5 \%$ peternak menggunakan tenaga kerja luar untuk mencari hijauan.

Produktivitas teknis usahaternak sapi potong di kecamatan Tumpang masih belum efisien dari nilai 3,1 ST/hari karena jumlah ternak yang sedikit. Tingkat partisipasi anak terhadap usahaternak sapi potong hanya $11 \%$ yang ikut berkontribusi dalam pengembangan usaha sapi potong. Faktor-faktor yang berpengaruh terhadap produktivitas teknik tenaga kerja usahaternak sapi potong di Kecamatan Tumpang adalah Jumlah tenaga kerja, jumlah ternak dan tingkat partisipasi anak dalan usahaternak sapi potong.

\section{DAFTAR PUSTAKA}

Achmad, B., R.H. Purwanto, S. Sabarnurdin, \& Sumardi. 2015. Tingkat Pendapatan dan Curahan Tenaga Kerja pada Hutan Rakyat di Kabupaten Ciamis. Jurnal Ilmu Kehutanan 9 (2):105-116.
Ahmadi, A. 2003. Ilmu Pendidikan. Rineka Cipta. Jakarta.

Fajri, N.I, Taslim, \& Hermawan. 2016. Pengaruh Skala Usaha Sapi Perah Dan Curahan Tenaga Kerja Terhadap Pendapatan Peternak. Student e-journals Unpad 5(3). http://jurnal.unpad.ac.id/ejournal/article/v iew/9646 .

Ghozali.I \& H. Latan. 2012. Partial Least Squares Konsep, Metode dan Aplikasi Menggunakan Program WarpPLS 5.0.

Kay, R. D. dan Edward, W. M., 1994. Farm Management. Third Edition. Mc. GrawHill. Inc, Singapore.

Kementan. 2015. Rencana Strategis Kementerian Pertanian 2015-2019. Kementerian Pertanian RI. Jakarta.

Ratna. F.D.P. 2000. Analisis Produktivitas Tenaga Kerja Pada Usaha Peternakan Sapi Perah Rakyat Di Kecamatan Sukaraja Kabupaten Sukabumi Propinsi Jawa Barat. Sosial Ekonomi Pertanian. Institut Pertanian Bogor.

Siregar, N.W.P. 2013. Faktor-Faktor yang Mempengaruhi Usaha Ternak Sapi Potong di Desa Mangkai Lama Kecamatan Lima Puluh Kabupaten Batubara Provinsi Sumatera Utara. Departemen Agribisnis Fakultas Ekonomi dan Manajemen, Institut Pertanian Bogor. Bogor.

Sudono. 2003. Ilmu Produksi Ternak Perah. Jurusan Ilmu Produksi Ternak. Fakultas Peternakan. Institut Pertanian Bogor. Bogor

Tatipikalawan, J.M. 2012. Analisis Produktivitas Tenaga Kerja Keluarga pada Usaha Peternakan Kerbau di Pulau Moa Kabupaten Maluku Baratdaya. Jurnal Agroforestri 